\title{
Synthesis and preliminary assessment of the anticancer and Wnt/ק-catenin inhibitory activity of small amide libraries of fenamates and profens
}

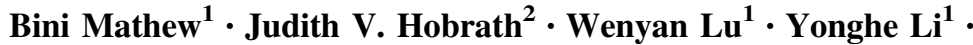 \\ Robert C. Reynolds $\mathbb{D}^{3}$
}

Received: 9 May 2017 / Accepted: 20 July 2017 / Published online: 5 August 2017

(C) The Author(s) 2017. This article is an open access publication

\begin{abstract}
As part of an ongoing program to study the anticancer activity of non-steroidal anti-inflammatory drugs (NSAIDs) through generating diversity libraries of multiple NSAID scaffolds, we synthesized a series of NSAID amide derivatives and screened these sets against three cancer cell lines (prostate, colon and breast) and $\mathrm{Wnt} / \beta$-catenin signaling. The evaluated amide analog libraries show significant anticancer activity/cell proliferation inhibition, and specific members of the sets show inhibition of $\mathrm{Wnt} / \beta$ catenin signaling.
\end{abstract}

Keywords NSAIDs $\cdot$ Fenamates $\cdot$ Amides $\cdot W n t / \beta$-catenin $\cdot$ Cancer

$\begin{array}{ll}\text { Abbreviations } \\ \text { COX } & \text { Cyclooxygenase } \\ \text { HLM } & \text { Human liver microsome } \\ \text { MW } & \text { Molecular weight } \\ \text { NSAIDs } & \text { Non-steroidal anti-inflammatory drugs } \\ \text { SSA } & \text { Sulindac sulfide amide }\end{array}$

Electronic supplementary material The online version of this article (doi:10.1007/s00044-017-2001-z) contains supplementary material, which is available to authorized users.

Robert C. Reynolds

rcr12lkt@uab.edu

1 Drug Discovery Division, Southern Research Institute, 2000 Ninth Avenue South, Birmingham, AL 35205, USA

2 Drug Discovery Unit, College of Life Sciences, University of Dundee, Dundee DD1 5EH, UK

3 Division of Hematology and Oncology, The University of Alabama at Birmingham, Birmingham, Alabama 35294, USA

\section{Introduction}

Non-steroidal anti-inflammatory drugs (NSAIDs) are the most widely used class of drugs for the treatment of pain and inflammation. The anti-inflammatory mechanism of the NSAIDs is attributed to the inhibition of the cyclooxygenases (COXs) and reducing the synthesis of prostaglandin signaling molecules (Vane 1971). There are two major isoforms of the COXs, COX-1 and COX-2. COX-1 is constitutively expressed in most tissues and plays an important role in tissue homeostasis, while COX-2 is induced as part of the acute inflammatory pathway. Epidemiological, preclinical and clinical studies have demonstrated the chemopreventive efficacy of NSAIDs by reducing cancer incidence in the general population by up to 50\% (Thun et al. 2002; Chan 2002; Reeder et al. 2004; Soh and Weinstein 2003). The depletion of physiologically important prostaglandins through chronic COX (COX-1 or COX-2) inhibition, however, can have significant life threatening side effects including gastrointestinal, renal, and cardiovascular toxicity (Cannon and Cannon 2012; Yu et al. 2012; Mukherjee 2002; Vane and Botting 1998; Vane et al. 1998). Unfortunately, these side effects limit the utility of NSAIDs for cancer chemoprevention, which tends to require high dosages and chronic treatment. NSAIDs are most commonly believed to display their anticancer effects through inhibition of COX-2, as this isozyme is thought to play a role in carcinogenesis and is often over expressed in human premalignant and malignant tissues (Brown and DuBois 2005; Husain et al. 2002; Eberhart et al. 1994). On the other hand, certain studies indicate that NSAIDs also promote apoptosis through mechanisms that are independent of COX inhibition. This proposition is further supported by the fact that compounds, structurally similar to NSAIDs but not significantly inhibiting COX isozymes, 
Fig. 1 General structures and substitutions of synthetic libraries

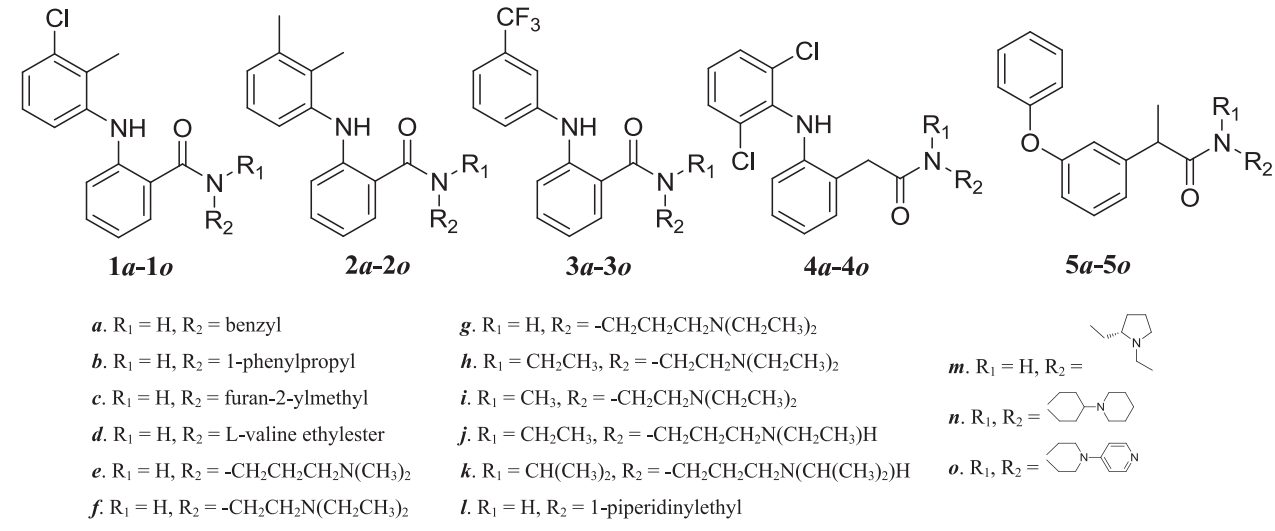

may have chemopreventive and proapoptotic properties (Piazza et al. 2010; Elder et al. 1997; Hanif et al. 1996; Alberts et al. 1995).

The Wnt/ $\beta$-catenin signaling pathway is a crucial player in the management of cell proliferation, migration, and differentiation, thus making it a powerful regulator of embryonic development and tumorigenesis (Barker and Clevers 2006). Wnt proteins are secreted glycoproteins that bind to the low-density lipoprotein receptor-related protein $5 / 6$ and Frizzled to activate $\mathrm{Wnt} / \beta$-catenin signaling. A large body of evidence suggests that there may be direct effects of NSAIDs on the Wnt/ $\beta$-catenin signaling pathway (Giardiello et al. 1993; Koehne and DuBois 2004; Jolly et al. 2002; Yang et al. 2003; Mahmoud et al. 1998; Boon et al. 2004; Gala and Chan 2015; Egashira et al. 2017; Preisner et al. 2015; Sareddy et al. 2013; Stein et al. 2011; Lu et al. 2009; Bombardo et al. 2017). For example, it was found that aspirin and indomethacin attenuate the transcription of $\beta$-catenin/TCF-responsive genes, by modulating T-cell factor (TCF) activity without disrupting $\beta$-catenin/ TCF complex formation (Dihlmann et al. 2001).

Fenamate NSAIDs, including tolfenamic, mefenamic and flufenamic acid have been derived from anthranilic acid, a close isosteric analog of salicylic acid. Salicylic acid is a metabolite of salicin and the active ingredient of the earliest anti-inflammatory herbal medicines, first isolated from willow bark. Interestingly, members of the NSAID fenamates and profens have been also shown effective for cancer prevention (Basha et al. 2011; Kang et al. 2012; Woo et al. 2004; Somchit et al. 2009; Lovering et al. 2004; Zhu et al. 1999; Mayorek et al. 2010; Marjanovic et al. 2007). We previously reported that a relatively simple alteration to sulindac in the form of sulindac sulfide amide (SSA) demonstrated excellent anticancer activity compared to the parent compound sulindac sulfide in vitro as well as having in vivo xenograft activity (Piazza et al. 2009). These findings inspired us to synthesize a series of libraries from other NSAID scaffolds, such as tolfenamic acid, mefenamic

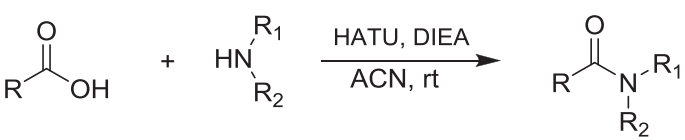

$$
\begin{aligned}
& 1-5 \quad a-o \quad(1-5) a-(1-5) o
\end{aligned}
$$

Scheme 1 General synthetic scheme to prepare NSAID amides

acid, flufenamic acid, diclofenac and fenoprofen, replacing the carboxylate with an amide functional group as in SSA in order to examine the anticancer activity of the amide libraries against three cancer cell lines (prostate, colon and breast). These compounds were further screened against Wnt/ $\beta$-catenin signaling to elucidate COX-independent mechanisms of their effects.

\section{Materials and methods}

\section{Chemistry}

Figure 1 shows the general structures of the amide diversity series: (1) tolfenamic amides; (2) mefenamic amides; (3) flufenamic amides; (4) diclofenac amides; and (5) and fenoprofen amides.

These compounds were prepared from the corresponding commercially available fenamates and fenoprofen by coupling with an amine set (a-o) using HATU (Carpino 1993) as the amide coupling reagent to afford compounds (1-5)a-(1-5)o in good yields (Scheme 1).

\section{Biological studies}

Quantitative high-throughput screen (qHTS) cell proliferation assays

All target compounds were screened against three cancer cell lines (prostate, colon and breast) using a qHTS format. 
In brief, liquid handling was performed on a Biomek FX with a 384-multichannel head. In 384 well plates, compounds were arrayed in columns 3-22 leaving 32 wells for positive and negative controls. All compounds were diluted together in a plate to plate transfer. Cells were then added to assay plates containing diluted compound using a Matrix/ Thermo wellmate. Cells were incubated with compound for three cell doublings. Due to differences in growth rates between cell lines, the incubation period for PC 3 and HT-29 cells was $72 \mathrm{~h}$, but was increased to $96 \mathrm{~h}$ for MDA-MB-231 cells. Plates were incubated for the appropriate time (72 or $96 \mathrm{~h}$ ) and cell viability was determined using Cell Titer Glo (Promega).

The dose response format employed a cross-plate method rather than an in-plate method, allowing for more efficient compound dilution and addition to assay plates. Two-fold dilutions of the compound mother plate were aliquoted to a series of 384-well plates using a stacked plate (or crossplate) format. Object manager was used to create the assay plates by replicating the compound mother plate and assigning concentration values to the assay plates. Luminescence values were read on the envision plate reader for each of the assay plates. The entire experiment of assay plates was set up in a single day with a complete read of all plates occurring at $72 \mathrm{~h}$ and or at $96 \mathrm{~h}$ as required for the cell lines. Data were imported and analyzed within $24 \mathrm{~h}$ of the endpoint read. From set up to final report, all data points were generated and reported within one week. Therefore, only a single passage was required for each cell line, eliminating potential variation due to passage and cell count.

Data were analyzed using Activity Base software (IDBS). Data were imported directly into the database and calculated using an ActivityBase XE template where the Virtual Plate functionality was employed to maintain the link between the assay plates and the compound mother plate from which they were created. For each plate the median, standard deviations, coefficient of variations and $Z$ values were calculated for the control wells. These values were used to assure quality and consistency across all test plates and to normalize percent cell viability for each well. XLFit and MathIQ were used within the ActivityBase XE template to plot the dose response curves and calculate $\mathrm{CC}_{50}$ values. The $\mathrm{CC}_{50} \mathrm{~s}$ were calculated by plotting the cell viability relative to the mean of the cell control at each of the tested compound concentration. Compounds that caused cell viability $<80 \%$ were considered active. Values were calculated only for active compounds using a 4-parameter Levenburg-Marquardt algorithm (XLFit \#205), with the maximum and minimum locked at 0 and 100 respectively. Data and graphical results were then reported and compared across the three cell lines.

\section{Wnt/ß-catenin signaling screens}

The effects of all target compounds on Wnt/ $\beta$-catenin signaling were examined with the Wnt reporter luciferase assay in HEK293 cells as previously described (Lu et al. 2011; Lu et al. 2012). In brief, cells were plated into 24 -well plates. After overnight culture, cells were transiently transfected with LRP6 plasmid (kindly provided by Dr. Christof Niehrs, Deutsches Krebsforschungszentrum, Heidelberg, Germany) along with the Wnt signaling reporter construct Super8XTOPFlash (kindly provided by Dr. Randall T. Moon, University of Washington, Seattle) and $\beta$ galactosidase-expressing vector (Promega) by FuGENE HD (Roche). After $24 \mathrm{~h}$ incubation, cells were treated with each individual compound at the indicated concentration. Cells were then lysed $24 \mathrm{~h}$ later and both luciferase and $\beta$-galactosidase activities were determined. The luciferase activity was normalized to the $\beta$-galactosidase activity. Initial activity was measured at $100 \mu \mathrm{M}$, and, typically for those compounds that showed $<50 \%$ activity relative to the control level and cancer cell line inhibition, a dose of $10 \mu \mathrm{M}$ was tested in order to determine if $\mathrm{Wnt} / \beta$-catenin activity was dose-dependent.

\section{Results and discussion}

\section{Screening results}

Table 1 lists the anticancer activity of tolfenamic amide analogs 1 against colon, prostate, and breast cancer cell lines as well as their Wnt/ $\beta$-catenin signaling data. Benzyl amide derivative of tolfenamic acid 1a displayed significant anticancer activity in all the three assays. 1-Phenylpropyl amide $\mathbf{1 b}$ exhibited moderate activity in colon, prostate and breast cancer assays with $\mathrm{CC}_{50}$ values of $15.92,25.37$ and $18.08 \mu \mathrm{M}$, respectively. Compound 1c with a furan-2ylmethyl group at the amide linker showed better inhibitory potency than $\mathbf{1 b}$, but was less potent than 1a. Interestingly, compounds 1a, $\mathbf{1 b}$ and $\mathbf{1 c}$ at $10 \mu \mathrm{M}$ significantly inhibited Wnt/ $\beta$-catenin signaling in HEK293 cells in a dosedependent manner as signaling activity decreased at the higher dose of $100 \mu \mathrm{M}$, suggesting that the inhibition of Wnt/ $\beta$-catenin signaling could contribute to anticancer activity.

The amino acid analog 1d led to a complete loss of potency in the proliferation assays although modest activity was seen at $100 \mu \mathrm{M}$ in the $\mathrm{Wnt} / \beta$-catenin signaling assay. Acyclic basic amide derivatives of tolfenamic acid 1e-1k displayed various levels of anticancer activity and $\mathrm{CC}_{50}$ values ranged from $6 \mu \mathrm{M}$ to $>50 \mu \mathrm{M}$. $N, N$-diethylethylamide derivative 1f and $N, N$-diethylpropylamide derivative $\mathbf{1 g}$ demonstrated similar activity against the three cell lines. 
Table 1 Anticancer and $\mathrm{Wnt} / \beta$ catenin signaling data of tolfenamic amides $\mathbf{1 a}-\mathbf{1 0}$

\begin{tabular}{|c|c|c|c|c|c|}
\hline \multirow[t]{2}{*}{ Cpd } & \multicolumn{3}{|c|}{ Cell Line $-\mathrm{CC}_{50}(\mu \mathrm{M})$} & \multicolumn{2}{|l|}{$\mathrm{Wnt} / \beta$-catenin } \\
\hline & HT29 & PC3 & MDA-MB-231 & $\%$ Control $(100 \mu \mathrm{M})$ & $\%$ Control $(10 \mu \mathrm{M})$ \\
\hline 1a & $0.99 \pm 0.35$ & $5.89 \pm 2.50$ & $7.27 \pm 6.61$ & $4.78 \pm 0.84$ & $30.66 \pm 2.88$ \\
\hline $1 b$ & $15.92 \pm 2.14$ & $25.37 \pm 4.38$ & $18.08 \pm 4.64$ & $13.23 \pm 3.89$ & $56.55 \pm 3.55$ \\
\hline 1c & $3.11 \pm 0.49$ & $9.43 \pm 1.16$ & $6.21 \pm 3.20$ & $8.40 \pm 0.74$ & $47.12 \pm 4.65$ \\
\hline $1 d$ & $>50$ & $>50$ & $>50$ & $51.15 \pm 3.41$ & ND \\
\hline $1 \mathrm{e}$ & $18.93 \pm 1.29$ & $26.42 \pm 2.86$ & $26.81 \pm 1.98$ & $66.61 \pm 7.70$ & ND \\
\hline 1f & $6.58 \pm 0.58$ & $7.92 \pm 0.87$ & $10.67 \pm 0.85$ & N/A & $148.21 \pm 0.63$ \\
\hline $1 g$ & $8.74 \pm 1.14$ & $13.29 \pm 1.56$ & $16.57 \pm 1.97$ & N/A & ND \\
\hline $1 \mathrm{~h}$ & $12.04 \pm 1.24$ & $35.05 \pm 1.96$ & $>50$ & $69.26 \pm 9.56$ & ND \\
\hline $\mathbf{1 i}$ & $20.02 \pm 1.83$ & $>50$ & $>50$ & $157.05 \pm 3.74$ & ND \\
\hline $\mathbf{1 j}$ & $17.33 \pm 1.64$ & $>50$ & $>50$ & $81.87 \pm 4.04$ & ND \\
\hline $1 \mathrm{k}$ & $6.05 \pm 0.58$ & $14.51 \pm 1.74$ & $16.68 \pm 1.82$ & N/A & $128.71 \pm 13.66$ \\
\hline 11 & $7.15 \pm 0.73$ & $9.56 \pm 0.83$ & $10.39 \pm 1.15$ & N/A & $163.73 \pm 7.58$ \\
\hline $1 \mathrm{~m}$ & $6.69 \pm 0.43$ & $8.19 \pm 0.77$ & $10.21 \pm 0.93$ & N/A & $179.39 \pm 6.78$ \\
\hline 1n & $11.31 \pm 1.31$ & $29.12 \pm 3.22$ & $21.11 \pm 1.30$ & $16.24 \pm 2.39$ & $129.82 \pm 7.08$ \\
\hline 10 & $5.43 \pm 0.28$ & $8.12 \pm 0.89$ & $14.15 \pm 1.03$ & N/A & $95.84 \pm 0.30$ \\
\hline
\end{tabular}

$N / A$ not available due to cell toxicity at this concentration, $N D$ not done

\begin{tabular}{|c|c|c|c|c|c|}
\hline \multirow[t]{2}{*}{ Cpd } & \multicolumn{3}{|c|}{ Cell line $-\mathrm{CC}_{50}(\mu \mathrm{M})$} & \multicolumn{2}{|l|}{ Wnt $/ \beta$-catenin } \\
\hline & HT29 & PC3 & MDA-MB-231 & $\%$ Control $(100 \mu \mathrm{M})$ & $\%$ Control $(10 \mu \mathrm{M}$ \\
\hline $2 \mathbf{a}$ & $5.93 \pm 0.95$ & $17.69 \pm 2.91$ & $17.35 \pm 9.25$ & $8.15 \pm 1.73$ & $64.46 \pm 0.36$ \\
\hline $2 \mathbf{b}$ & $31.50 \pm 3.63$ & $>50$ & $25.83 \pm 3.97$ & $42.15 \pm 4.53$ & $73.55 \pm 3.55$ \\
\hline $2 c$ & $12.06 \pm 1.21$ & $33.91 \pm 4.86$ & $10.78 \pm 2.65$ & $2.25 \pm 0.70$ & $59.64 \pm 7.64$ \\
\hline 2d & $>50$ & $>50$ & $>50$ & $47.19 \pm 6.36$ & ND \\
\hline $2 e$ & $>50$ & $>50$ & $>50$ & $255.95 \pm 59.07$ & ND \\
\hline $2 f$ & $11.52 \pm 0.88$ & $20.55 \pm 2.39$ & $19.21 \pm 2.08$ & N/A & $163.22 \pm 37.56$ \\
\hline $2 \mathrm{~g}$ & $15.14 \pm 0.41$ & $33.82 \pm 4.77$ & $27.44 \pm 1.64$ & $196.32 \pm 9.61$ & ND \\
\hline $2 \mathrm{~h}$ & $19.68 \pm 0.84$ & $>50$ & $>50$ & $178.13 \pm 9.46$ & ND \\
\hline $2 \mathbf{i}$ & $39.45 \pm 2.33$ & $>50$ & $>50$ & $189.74 \pm 10.96$ & ND \\
\hline $2 \mathbf{j}$ & $28.55 \pm 0.88$ & $>50$ & $>50$ & $179.79 \pm 15.34$ & ND \\
\hline $2 \mathbf{k}$ & $12.98 \pm 0.39$ & $29.06 \pm 2.98$ & $30.81 \pm 1.73$ & $18.84 \pm 2.24$ & ND \\
\hline 21 & $6.08 \pm 0.38$ & $10.41 \pm 1.29$ & $11.32 \pm 1.35$ & N/A & $132.88 \pm 10.51$ \\
\hline $2 \mathrm{~m}$ & $8.27 \pm 0.45$ & $9.82 \pm 1.11$ & $13.20 \pm 0.43$ & N/A & $174.42 \pm 37.71$ \\
\hline $2 n$ & $19.51 \pm 0.94$ & $>50$ & $>50$ & $144.22 \pm 7.82$ & ND \\
\hline 20 & $8.73 \pm 0.61$ & $20.45 \pm 2.55$ & $>50$ & $100.10 \pm 8.28$ & ND \\
\hline
\end{tabular}

N/A not available due to cell toxicity at this concentration, $N D$ not done
Table 2 Anticancer and $\mathrm{Wnt} / \beta$ catenin signaling data of mefenamic amides $\mathbf{2 a - 2 o}$. these four compounds, 1-piperidinylethyl analog $\mathbf{1 l}$ and 1ethylpyrrolidinylmethyl analog $\mathbf{1 m}$ have similar activity and 4-pyridylpiperazine derivative 10 displayed slightly better anticancer activity than the other three examples. Notably, compounds 1d-1o displayed weak activity at best against Wnt/ $\beta$-catenin signaling in HEK293 cells.

Screening data for the mefenamic amide series 2 are shown in Table 2. In general, compounds (2a-2o) showed modestly decreased cell growth inhibition potency 
Table 3 Anticancer and $\mathrm{Wnt} / \beta$ catenin signaling data of flufenamic amides $\mathbf{3 a}-\mathbf{3 o}$

\begin{tabular}{|c|c|c|c|c|c|}
\hline \multirow[t]{2}{*}{$\mathrm{Cpd}$} & \multicolumn{3}{|c|}{ Cell Line $-\mathrm{CC}_{50}(\mu \mathrm{M})$} & \multicolumn{2}{|l|}{ Wnt $/ \beta$-catenin } \\
\hline & HT29 & PC3 & MDA-MB-231 & $\%$ Control $(100 \mu \mathrm{M})$ & $\%$ Control $(10 \mu \mathrm{M})$ \\
\hline $\mathbf{3 a}$ & $7.75 \pm 1.29$ & $19.79 \pm 3.03$ & $22.55 \pm 9.86$ & $4.56 \pm 0.08$ & $62.33 \pm 7.32$ \\
\hline $3 \mathbf{b}$ & $35.64 \pm 4.04$ & $>50$ & $32.07 \pm 3.34$ & $9.10 \pm 0.72$ & $74.87 \pm 8.54$ \\
\hline $3 c$ & $15.11 \pm 1.17$ & $27.38 \pm 2.60$ & $17.91 \pm 3.61$ & $6.89 \pm 7.98$ & $70.49 \pm 8.01$ \\
\hline $3 d$ & $>50$ & $>50$ & $>50$ & $33.31 \pm 0.43$ & ND \\
\hline $3 e$ & $17.82 \pm 0.73$ & $41.33 \pm 6.50$ & $41.44 \pm 2.07$ & $152.99 \pm 13.15$ & ND \\
\hline 3f & $8.16 \pm 0.48$ & $15.45 \pm 1.78$ & $14.78 \pm 1.25$ & N/A & ND \\
\hline $3 g$ & $16.58 \pm 0.68$ & $33.89 \pm 2.63$ & $29.88 \pm 2.24$ & $95.15 \pm 7.59$ & ND \\
\hline $3 \mathbf{h}$ & $23.55 \pm 1.14$ & $>50$ & $>50$ & $124.87 \pm 3.64$ & ND \\
\hline $3 \mathbf{i}$ & $39.92 \pm 2.45$ & $>50$ & $>50$ & $156.09 \pm 3.79$ & ND \\
\hline $3 \mathbf{j}$ & $38.76 \pm 2.60$ & $>50$ & $>50$ & $119.75 \pm 5.61$ & ND \\
\hline $3 \mathbf{k}$ & $10.63 \pm 0.26$ & $25.25 \pm 2.98$ & $24.12 \pm 2.35$ & $39.83 \pm 5.51$ & ND \\
\hline 31 & $7.06 \pm 0.65$ & $13.21 \pm 1.69$ & $15.71 \pm 0.89$ & N/A & $153.34 \pm 8.53$ \\
\hline $3 \mathrm{~m}$ & $7.83 \pm 0.35$ & $10.44 \pm 0.99$ & $12.02 \pm 0.53$ & N/A & $131.68 \pm 2.86$ \\
\hline $3 n$ & $22.82 \pm 0.74$ & $>50$ & $>50$ & $80.49 \pm 6.54$ & ND \\
\hline 30 & $11.17 \pm 0.47$ & $17.14 \pm 1.45$ & $30.39 \pm 3.00$ & $5.31 \pm 1.92$ & ND \\
\hline
\end{tabular}

$N / A$ not available due to cell toxicity at this concentration, $N D$ not done compared to the tolfenamic amide series 1a-1o. Among this series, benzyl amide derivative 2a, 1-piperidinylethyl derivative $\mathbf{2 l}$, 1-ethylpyrrolidinylmethyl derivative $\mathbf{2 m}$, and 4-pyridylpiperazine derivative $\mathbf{2 0}$ are the most active compounds with $\mathrm{CC}_{50}$ values ranging from 5 to $9 \mu \mathrm{M}$ against the HT-29 cell line. Moreover, benzyl amide derivative 2a also suppressed Wnt/ $\beta$-catenin signaling in HEK293 cells with activity that was modestly less than the related tolfenamic amides 1a. Similar results were seen with analog $\mathbf{2 c}$ as compared to the related compound $\mathbf{1 c}$.

Our results for the flufenamic amides $\mathbf{3}$ are summarized in Table 3. The activity pattern of these compounds (3a-3o) is very similar to the mefenamic amide series $\mathbf{2 a - 2 0}$. Compounds 3a (benzyl amide), $\mathbf{3 f}(N, N$-diethylethyl amide), 3k (N-isopropylpropyl amide), 31 (1-piperidinylethyl amide), 3m (1-ethylpyrrolidinylmethyl amide) and 3o (4pyridylpiperazine amide) showed moderate activity in all the three assays. However, compounds 3a-3o displayed modest to little activity against $\mathrm{Wnt} / \beta$-catenin signaling in HEK293 cells although the amides $\mathbf{3 a}-\mathbf{3 c}$ consistently were higher in activity as in tolfenamic amides (1) and mefenamic amide (2) series.

We next turned our attention to anticancer activity of diclofenac amides 4a-4o (Table 4).

In this series, acyclic (4e-4k) and cyclic (4l-4o) basic amide compounds exhibited significant inhibitory activity against cancer. The activity of aromatic amides was relatively weak. Among the acyclic series, $\mathrm{N}$-isopropylpropyl amide derivative $\mathbf{4 k}$ displayed relatively potent activity against all three cell lines. Compound 4o, with a 4pyridylpiperazine group at the amide linker, was found to be more active than other compounds in the cyclic amide series. Notably, compounds $\mathbf{4 a - 4 o}$ displayed no or weak activity against Wnt/ $\beta$-catenin signaling in HEK293 cells.

We next examined the anticancer activity of corresponding fenoprofen analogs 5 (Table 5). None of these compounds, except $\mathrm{N}$-isopropylpropyl amide analog $\mathbf{5} \mathbf{k}$ and 4-pyridylpiperazine amide analog 5o, exhibited good activity. Furthermore, compounds $\mathbf{5 a - 5 o}$ displayed weak activity at best against Wnt/ $\beta$-catenin signaling in HEK293 cells.

\section{In silico evaluation of lipophilicity/physicochemical properties}

Compounds that have attractive physicochemical properties, such as cell permeability and metabolic stability are more likely to succeed as lead candidates in early drop development. $\log \mathrm{D}$ and the molecular weight (MW) have been identified as properties showing correlation with permeability and stability data available for large data sets (Waring 2009; Johnson et al. 2009). Using Caco-2 permeability data for 16,227 compounds and human liver microsome (HLM) stability determined for 47,018 compounds, optimal ranges for $\log \mathrm{D}$ and MW have been derived that describe compounds meeting both requirements, good permeability and HLM stability (Johnson et al. 2009). On a plot of MW versus $\log D$ these optimal ranges cover a triangular area with baseline at MW 200 and $\log \mathrm{D}$ -2 to 5 and an apex at MW 450 between $\log \mathrm{D} 1$ to 2 , referred to as the Golden Triangle area. Several analogs from each presented series map to the Golden Triangle area, 
Table 4 Anticancer and $\mathrm{Wnt} / \beta$ catenin signaling data of diclofenac amides $\mathbf{4 a}-\mathbf{4 o}$

\begin{tabular}{lllllll}
\hline Cpd & \multicolumn{2}{l}{ Cell Line $-\mathrm{CC}_{50}(\mu \mathrm{M})$} & & Wnt/ $\beta$-catenin & \\
\cline { 2 - 3 } & HT29 & PC3 & MDA-MB-231 & & \% Control $(100 \mu \mathrm{M})$ & \% Control $(10 \mu \mathrm{M})$ \\
\hline $\mathbf{4 a}$ & $>50$ & $31.82 \pm 9.34$ & $30.75 \pm 7.76$ & & $131.26 \pm 52.55$ & ND \\
$\mathbf{4 b}$ & $>50$ & $>50$ & $>50$ & $15.97 \pm 3.91$ & ND \\
$\mathbf{4 c}$ & $>50$ & $35.47 \pm 10.32$ & $49.33 \pm 6.53$ & & $52.36 \pm 5.34$ & ND \\
$\mathbf{4 d}$ & $>50$ & $32.82 \pm 5.34$ & $42.07 \pm 7.57$ & & $13.51 \pm 11.78$ & $117.56 \pm 4.50$ \\
$\mathbf{4 e}$ & $18.72 \pm 1.29$ & $>50$ & $42.21 \pm 4.98$ & & $132.99 \pm 25.46$ & ND \\
$\mathbf{4 f}$ & $5.48 \pm 0.20$ & $16.87 \pm 2.63$ & $19.09 \pm 2.52$ & & N/A & $200.60 \pm 18.09$ \\
$\mathbf{4 g}$ & $7.52 \pm 0.28$ & $22.26 \pm 2.00$ & $18.71 \pm 0.85$ & & N/A & $173.75 \pm 4.36$ \\
$\mathbf{4 h}$ & $7.25 \pm 0.28$ & $14.26 \pm 1.61$ & $25.15 \pm 2.68$ & & N/A & $163.92 \pm 5.45$ \\
$\mathbf{4 i}$ & $8.85 \pm 0.32$ & $22.42 \pm 2.00$ & $29.67 \pm 1.61$ & & $11.90 \pm 7.28$ & $151.45 \pm 5.82$ \\
$\mathbf{4 j}$ & $7.21 \pm 0.43$ & $10.83 \pm 1.58$ & $19.16 \pm 1.59$ & & N/A & $134.87 \pm 13.58$ \\
$\mathbf{4 k}$ & $4.56 \pm 0.15$ & $6.65 \pm 0.74$ & $9.11 \pm 0.32$ & & N/A & $138.80 \pm 0.96$ \\
$\mathbf{4 l}$ & $6.29 \pm 0.18$ & $10.75 \pm 1.25$ & $14.97 \pm 1.16$ & & N/A & $190.60 \pm 14.46$ \\
$\mathbf{4 m}$ & $6.42 \pm 0.57$ & $13.17 \pm 1.46$ & $13.51 \pm 1.12$ & & N/A & $186.88 \pm 12.50$ \\
$\mathbf{4 n}$ & $10.15 \pm 0.49$ & $19.8 \pm 2.34$ & $16.64 \pm 0.93$ & & $6.39 \pm 1.66$ & ND \\
$\mathbf{4 o}$ & $3.51 \pm 0.35$ & $10.33 \pm 1.72$ & $16.57 \pm 1.33$ & & $181.77 \pm 61.37$ & ND \\
\hline
\end{tabular}

N/A not available due to cell toxicity at this concentration, $N D$ not done

\begin{tabular}{|c|c|c|c|c|c|}
\hline \multirow[t]{2}{*}{ Cpd } & \multicolumn{3}{|c|}{ Cell Line $-\mathrm{CC}_{50}(\mu \mathrm{M})$} & \multicolumn{2}{|l|}{$\mathrm{Wnt} / \beta$-catenin } \\
\hline & HT29 & PC3 & MDA-MB-231 & $\%$ Control $(100 \mu \mathrm{M})$ & $\%$ Control $(10 \mu \mathrm{M})$ \\
\hline $5 a$ & $>50$ & $>50$ & $>50$ & $9.60 \pm 1.54$ & $109.27 \pm 12.08$ \\
\hline $5 \mathbf{b}$ & $>50$ & $>50$ & $>50$ & $6.77 \pm 0.39$ & $114.35 \pm 18.16$ \\
\hline $5 c$ & $>50$ & $>50$ & $>50$ & $71.24 \pm 10.54$ & ND \\
\hline $5 d$ & $>50$ & $>50$ & $>50$ & $4.76 \pm 43$ & $79.12 \pm 6.12$ \\
\hline $5 e$ & $>50$ & $>50$ & $>50$ & $82.57 \pm 4.03$ & ND \\
\hline $5 f$ & $29.6 \pm 2.04$ & $>50$ & $>50$ & $131.04 \pm 5.43$ & ND \\
\hline $5 \mathrm{~g}$ & $35.72 \pm 9.18$ & $>50$ & $>50$ & $139.50 \pm 13.04$ & ND \\
\hline $5 \mathrm{~h}$ & $15.07 \pm 1.57$ & $>50$ & $>50$ & $77.34 \pm 5.76$ & $116.65 \pm 11.31$ \\
\hline $5 i$ & $23.11 \pm 3.60$ & $>50$ & $>50$ & $114.07 \pm 18.30$ & ND \\
\hline $\mathbf{5 j}$ & $17.57 \pm 1.28$ & $41.3 \pm 3.34$ & $>50$ & $140.26 \pm 18.54$ & ND \\
\hline $5 \mathbf{k}$ & $7.46 \pm 0.63$ & $24.01 \pm 3.84$ & $30.8 \pm 7.06$ & $24.76 \pm 4.86$ & $131.90 \pm 7.46$ \\
\hline 51 & $20.37 \pm 1.82$ & $>50$ & $>50$ & $125.69 \pm 7.98$ & ND \\
\hline $5 \mathrm{~m}$ & $28.51 \pm 3.16$ & $>50$ & $>50$ & $92.17 \pm 8.49$ & ND \\
\hline $5 n$ & $13.83 \pm 1.30$ & $>50$ & $>50$ & $101.52 \pm 10.31$ & ND \\
\hline 50 & $7.9 \pm 0.84$ & $11.51 \pm 0.90$ & $13.22 \pm 2.35$ & $8.51 \pm 1.30$ & $82.33 \pm 3.50$ \\
\hline
\end{tabular}

$N D$ not done

Table 5 Anticancer and $\mathrm{Wnt} / \beta$ catenin signaling data of fenoprofen amides $\mathbf{5 a}-\mathbf{5 0}$ identified with labeled data points in the MW versus $\log \mathrm{D}$ plot (Supplemental materials), where $\log \mathrm{D}$ values were computed using StarDrop (version 6.2.0). For example, these optimal ranges are satisfied by analogs with promising activities, such as $\mathbf{2 m}(\log \mathrm{D} 2.77$, MW 351.5), 5k $(\log \mathrm{D}$ 2.08, MW 382.5), 5o $(\log \mathrm{D} 2.66$, MW 387.5). These compounds are predicted to possess optimal values associated with good permeability and metabolic stability properties. Metabolically labile site predictions included in
Supplemental materials support that compound 5o has minimal metabolic liabilities and predicts that it has a low estimated efficiency of CYP3A4 metabolism as computed based on all metabolic sites in the molecule. In the case of compound $\mathbf{5 k}$, a single labile site is predicted at the isopropylamine group suggesting redesign of this group to achieve enhanced metabolic stability for this scaffold. The remainder of labile sites in $\mathbf{5 k}$ are predicted to be relatively stable or moderately stable to metabolism. Overall, both 
compounds $\mathbf{5 0}$ and $\mathbf{5 k}$ have reduced metabolic liability and vulnerability compared to other scaffolds, for example as predicted for the lead NSAID analog SSA (please see Supplemental materials).

LogD values computed for compounds in series 1-3 (Tables 1-3) show linear correlation with suppression of $\mathrm{Wnt} / \beta$-catenin signaling at $10 \mu \mathrm{M}$ ( $r^{2}$ equals 0.74$)$, while at $100 \mu \mathrm{M}$ drug concentration the analogous correlation is weak ( $r^{2}$ equals 0.39 ). The correlation plot (included in Supplemental materials) suggests that higher $\log \mathrm{D}$ values are associated with more potent $\mathrm{Wnt} / \beta$-catenin activities (at $10 \mu \mathrm{M})$. Caco-2 cell permeability descriptors computed using Schrödinger software predict that all compounds in this study fall in the range associated with high permeability, except for analogs containing substitution $d$ in Fig. 1, which are predicted moderately permeable. StarDrop software tools predict all compounds permeable (human intestinal absorption $>30 \%$ ). While the presented compounds cover a wide range of $\log \mathrm{D}$ (1.66 to 5.96), nearly all compounds are predicted highly permeable. Further, we found no correlation between the computed $\log \mathrm{D}$ and cancer cell line data for compounds in series 1-3. For compounds in series 4-5 (Tables 4-5), there was no notable correlation between computed $\log \mathrm{D}$ values and cancer cell line or $\mathrm{Wnt} / \beta$-catenin activities.

Thus, computed $\log \mathrm{D}$ may be correlated with $\mathrm{Wnt} / \beta$ catenin suppression for analogs in Tables 1-3, however, no analogous correlation was found with cancer cell line activities. Based on in silico predictions cell permeability properties may not be linked to the predicted effect of $\log \mathrm{D}$ on $\mathrm{Wnt} / \beta$-catenin activities.

\section{Conclusions}

We synthesized a series of amide libraries from NSAID scaffolds tolfenamic acid, mefenamic acid, flufenamic acid, diclofenac and fenoprofen. These compound sets were evaluated for their anticancer and $\mathrm{Wnt} / \beta$-catenin signaling activity. Our observations indicated that the benzyl amide derivative of tolfenamic acid 1a may be a possible candidate for further study relating to the effects of this class on Wnt/ $\beta$-catenin signaling. It is notable that a number of related analogs show significant inhibition of cell proliferation in the three target cell lines although there appears to be little inhibition of $\mathrm{Wnt} / \beta$-catenin signaling. As a class, the NSAIDs have been shown to have a variety of cellular activities, and this result is not surprising. We continue to examine the chemical biology of the various NSAID scaffolds with the goal of identifying specific targets that might allow further development of new and improved inhibitors of these targets showing greater potency and selective anticancer activity. A number of analogs from each series are predicted to have acceptable physicochemical properties for consideration in future studies. Among these, analogs $\mathbf{2 m}, \mathbf{5 k}$ and $\mathbf{5 0}$ are highlighted for possible advancement in vivo.

Acknowledgements We are grateful to Drs. Christof Niehrs and Randall T. Moon for their generosity in providing reagents. This work was supported by grants from the National Institutes of Health NCI 1R01CA131378 (RCR PI) and RO1CA124531 (Y. Li PI). We also acknowledge DOD Era of Hope award W81XWH-07-1-0463 (RCR PI) for supporting HTS cancer cell activity profiling. We thank the University of Alabama at Birmingham, Department of Hematology and Oncology for their support. We also thank both Lucile White and Lynn Rasmussen for HTS support services.

\section{Compliance with ethical standards}

Conflict of interest The authors declare that they have no competing interests.

Open Access This article is distributed under the terms of the Creative Commons Attribution 4.0 International License (http://crea tivecommons.org/licenses/by/4.0/), which permits unrestricted use, distribution, and reproduction in any medium, provided you give appropriate credit to the original author(s) and the source, provide a link to the Creative Commons license, and indicate if changes were made.

\section{References}

Alberts DS, Hixson L, Ahnen D, Bogert C, Einspahr J et al. (1995) Do NSAIDs exert their colon cancer chemoprevention activities through the inhibition of mucosal prostaglandin synthetase? J Cell Biochem Suppl 22:18-23

Barker N, Clevers H (2006) Mining the Wnt pathway for cancer therapeutics. Nat Rev Drug Discov 5:997-1014

Basha R, Ingersoll SB, Sankpal UT, Ahmad S, Baker CH et al. (2011) Tolfenamic acid inhibits ovarian cancer cell growth and decreases the expression of c-Met and survivin through suppressing specificity protein transcription factors. Gynecol Oncol 122:163-170

Boon EM, Keller JJ, Wormhoudt TA, Giardiello FM, Offerhaus GJ et al. (2004) Sulindac targets nuclear beta-catenin accumulation and Wnt signalling in adenomas of patients with familial adenomatous polyposis and in human colorectal cancer cell lines. $\mathrm{Br}$ J Cancer 90:224-229

Bombardo M, Malagola E, Chen R, Rudnicka A, Graf R, Sonda S (2017) Ibuprofen and diclofenac treatments reduce proliferation of pancreatic acinar cells upon inflammatory injury and mitogenic stimulation. Br J Pharmacol. doi: 10.1111/bph.13867

Brown JR, DuBois RN (2005) COX-2: a molecular target for colorectal cancer prevention. J Clin Oncol 23:2840-2855

Cannon CP, Cannon PJ (2012) COX-2 inhibitors and cardiovascular risk. Science336:1386-1387

Carpino LA (1993) 1-Hydroxy-7-azabenzotriazole - an efficient peptide coupling additive. J Am Chem Soc 115:4397-4398

Chan TA (2002) Nonsteroidal anti-inflammatory drugs, apoptosis, and colon-cancer chemoprevention. Lancet Oncol 3:166-174

Dihlmann S, Siermann A, von Knebel Doeberitz M (2001) The nonsteroidal anti-inflammatory drugs aspirin and indomethacin attenuate beta-catenin/TCF-4 signaling. Oncogene 20:645-653 
Eberhart CE, Coffey RJ, Radhika A, Giardiello FM, Ferrenbach S et al. (1994) Up-regulation of cyclooxygenase 2 gene expression in human colorectal adenomas and adenocarcinomas. Gastroenterology 107:1183-1188

Egashira I, Takahashi-Yanaga F, Nishida R, Arioka M, Igawa K et al. (2017) Celecoxib and 2,5-dimethylcelecoxib inhibit intestinal cancer growth by suppressing the $\mathrm{Wnt} / \beta$-catenin signaling pathway. Cancer Sci 108:108-115

Elder DJ, Halton DE, Hague A, Paraskeva C (1997) Induction of apoptotic cell death in human colorectal carcinoma cell lines by a cyclooxygenase-2 (COX-2)-selective nonsteroidal antiinflammatory drug: independence from $\mathrm{COX}-2$ protein expression. Clin Cancer Res 3:1679-1683

Gala MK, Chan AT (2015) Molecular pathways: aspirin and Wnt signaling-a molecularly targeted approach to cancer prevention and treatment. Clin Cancer Res 21:1543-1548

Giardiello FM, Hamilton SR, Krush AJ, Piantadosi S, Hylind LM et al. (1993) Treatment of Colonic and Rectal Adenomas with Sulindac in Familial Adenomatous Polyposis. N Engl J Med 328:1313-1316

Hanif R, Pittas A, Feng Y, Koutsos MI, Qiao L et al. (1996) Effects of nonsteroidal anti-inflammatory drugs on proliferation and on induction of apoptosis in colon cancer cells by a prostaglandinindependent pathway. Biochem Pharmacol 52:237-245

Husain SS, Szabo IL, Tamawski AS (2002) NSAID inhibition of GI cancer growth: clinical implications and molecular mechanisms of action. Am J Gastroenterol 97:542-553

Johnson TW, Dress KR, Edwards M (2009) Using the Golden Triangle to optimize clearance and oral absorption. Bioorg Med Chem Lett 19:5560-5564

Jolly K, Cheng KK, Langman MJS (2002) NSAIDs and gastrointestinal cancer prevention. Drugs 62:945-956

Kang SU, Shin YS, Hwang HS, Baek SJ, Lee SH et al. (2012) Tolfenamic acid induces apoptosis and growth inhibition in head and neck cancer: involvement of NAG-1 expression. PLoS One 7: e34988

Koehne CH, DuBois RN (2004) COX-2 inhibition and colorectal cancer. Semin Oncol 31:12-21

Lovering AL, Ride JP, Bunce CM, Desmond JC, Cummings SM et al. (2004) Crystal structures of prostaglandin D-2 11-ketoreductase (AKR1C3) in complex with the nonsteroidal anti-inflammatory drugs flufenamic acid and indomethacin. Cancer Res 64:1802-1810

Lu W, Lin C, King TD, Chen H, Reynolds RC et al. (2012) Silibinin inhibits Wnt/beta-catenin signaling by suppressing Wnt coreceptor LRP6 expression in human prostate and breast cancer cells. Cell Signal 24:2291-2296

Lu WY, Lin CH, Roberts MJ, Waud WR, Piazza GA et al. (2011) Niclosamide suppresses cancer cell growth by inducing Wnt coreceptor LRP6 degradation and inhibiting the Wnt/beta-catenin pathway. Plos One 6:e29290

Lu W, Tinsley HN, Keeton A, Qu Z, Piazza GA et al. (2009) Suppression of Wnt/beta-catenin signaling inhibits prostate cancer cell proliferation. Eur J Pharmacol 602:8-14

Mahmoud NN, Boolbol SK, Dannenberg AJ, Mestre JR, Bilinski RT et al. (1998) The sulfide metabolite of sulindac prevents tumors and restores enterocyte apoptosis in a murine model of familial adenomatous polyposis. Carcinogenesis 19:87-91

Marjanovic M, Zorc B, Pejnovic L, Zovko M, Kralj M (2007) Fenoprofen and ketoprofen amides as potential antitumor agents. Chem Biol Drug Des 69:222-226
Mayorek N, Naftali-Shani N, Grunewald M (2010) Diclofenac inhibits tumor growth in a murine model of pancreatic cancer by modulation of VEGF levels and arginase activity. PLoS One 5:e12715

Mukherjee D (2002) Selective cyclooxygenase-2 (COX-2) inhibitors and potential risk of cardiovascular events. Biochem Pharmacol 63:817-821

Piazza GA, Keeton AB, Tinsley HN, Gary BD, Whitt JD et al. (2009) A novel sulindac derivative that does not inhibit cyclooxygenases but potently inhibits colon tumor cell growth and induces apoptosis with antitumor activity. Cancer Prev Res (Phila) 2:572-580

Piazza GA, Keeton AB, Tinsley HN, Whitt JD, Gary BD et al. (2010) NSAIDs: old drugs reveal new anticancer targets. Pharmaceuticals 3:1652-1667

Preisner A, Albrecht S, Cui QL, Hucke S, Ghelman J et al. (2015) Non-steroidal anti-inflammatory drug indometacin enhances endogenous remyelination. Acta Neuropathol. 130:247-261

Reeder MK, Pamakcu R, Weinstein IB, Hoffman K, Thompson WJ (2004) Promising cancer chemopreventive agents. In: Kelloff GJ, Hawk ET, Sigman CC (eds) Cancer chemoprevention, vol. I. Humana, Totowa, NJ, p 401

Sareddy GR, Kesanakurti D, Kirti PB, Babu PP (2013) Nonsteroidal anti-inflammatory drugs diclofenac and celecoxib attenuates Wnt/ $\beta$-catenin/Tcf signaling pathway in human glioblastoma cells. Neurochem Res 38:2313-2322

Soh JW, Weinstein IB (2003) Role of COX-independent targets of NSAIDs and related compounds in cancer prevention and treatment. Prog Exp Tumor Res 37:261-285

Somchit MN, Faizah S, Zuraini A, Khairi HM, Hasiah AH et al. (2009) Selective in vitro cytotoxic effects of piroxicam and mefenamic acid on several cancer cells lines. Res J Pharmacol 3:15-18

Stein U, Arlt F, Smith J, Sack U, Herrmann P et al. (2011) Intervening in $\beta$-catenin signaling by sulindac inhibits S100A4-dependent colon cancer metastasis. Neoplasia 13:131-144

Thun MJ, Henley SJ, Patrono C (2002) Nonsteroidal antiinflammatory drugs as anticancer agents: mechanistic, pharmacologic, and clinical issues. J Natl Cancer Inst 94:252-266

Vane JR (1971) Inhibition of prostaglandin synthesis as a mechanism of action for aspirin-like drugs. Nat New Biol 231:232-235

Vane JR, Bakhle YS, Botting RM (1998) Cyclooxygenases 1 and 2. Annu Rev Pharmacol Toxicol 38:97-120

Vane JR, Botting RM (1998) Mechanism of action of antiinflammatory drugs. Int J Tissue React 20:3-15

Waring MJ (2009) Defining optimum lipophilicity and molecular weight ranges for drug candidates -Molecular weight dependent lower $\log \mathrm{D}$ limits based on permeability. Bioorg Med Chem Lett 19:2844-2851

Woo DH, Han IS, Jung G (2004) Mefenamic acid-induced apoptosis in human liver cancer cell-lines through caspase-3 pathway. Life Sci 75:2439-2449

Yang K, Fan K, Kurihara N, Shinozaki H, Rigas B et al. (2003) Regional response leading to tumorigenesis after sulindac in small and large intestine of mice with Apc mutations. Carcinogenesis 24:605-611

Yu Y, Ricciotti E, Scalia R, Tang SY, Grant G et al. (2012) Vascular COX-2 modulates blood pressure and thrombosis in mice. Sci Transl Med 4:132ra154

Zhu W, Smith A, Young CY (1999) A nonsteroidal anti-inflammatory drug, flufenamic acid, inhibits the expression of the androgen receptor in LNCaP cells. Endocrinology 140:5451-5454 